\title{
STRATEGI PENGELOLAAN EKOSISTEM TERUMBU KARANG DI DAERAH WISATA AIR TANJUNG BENOA DAN JEMELUK AMED, BALI
}

\author{
Ni Made Ary Widiastiti ${ }^{1 *}$, I Wayan Arthana ${ }^{1,2)}$, Ida Ayu Astarini ${ }^{1,3)}$ \\ ${ }^{1)}$ Program Studi Magister Ilmu Lingkungan, Pascasarjana, Universitas Udayana, J1 PB \\ Sudirman Denpasar, Bali. \\ ${ }^{2)}$ Fakultas Kelautan dan Perikanan, Universitas Udayana, Kampus Bukit Jimbaran, \\ Badung Bali \\ ${ }^{3)}$ Program Studi Biologi, Fakultas Matematika dan Ilmu Pengetahuan Alam, Universitas \\ Udayana, Kampus Bukit Jimbaran, Badung, Bali \\ *E-mail: dekarywidiastiti@gmail.com
}

\section{ABSTRACT \\ CORAL ECOSYSTEM MANAGEMENT STRATEGY IN TOURISM SITE TANJUNG BENOA AND JEMELUK AMED, BALI}

Tanjung Benoa and Jemeluk Amed are two famous marine tourism sites in Bali. This study aims to determine the state of coral ecosystem in its life form, factors associated with coral damage, and the strategy to manage coral in those two area. We used two methods: Line Intercept Transect (LIT) and SWOT. The live coral coverage condition in Tanjung Benoa is in moderate and worse category. While the Jemeluk Amed is in moderate level and good condition, respectively. Factors causing damage to coral ecosystem are: the corals are under pressure, some corals are already bleaching, the anchoring activity and oil spill from ships, and algae. The coral reefs ecosystem in Tanjung Benoa and Jemeluk Amed can be sustained in good condition with government support and NGOs in the development of environmentally friendly activities and monitoring studies, implementation of coral reef preservation rules (prohibition of taking coral reefs) and colaboration of the community, government, and NGOs to carry out coral reef rehabilitation and monitoring studies. As one of the tourism area in Bali, the role of universities are needed for continuous research on the state of coral reefs to maintain environmentally friendly and sustainable tourism.

Keywords: Coral reef; Life form; Strategy; Marine conservation.

\section{PENDAHULUAN}

Indonesia memiliki lautan luas terbentang dari Sabang sampai Merauke, menyimpan kekayaan laut yang melimpah. Pemanfaatan dan pelestariannya membutuhkan perhatian dan kesadaran tersendiri sehingga selalu terjaga keberadaannya dari generasi ke generasi. Salah satu kekayaan laut tersebut adalah terumbu karang (coral reef) yang sangat penting untuk dilestarikan (Ikawati dkk, 2001). Ekosistem terumbu karang merupakan sumber keanekaragaman hayati yang mempunyai peranan ekologi antara lain: sumber makanan, berlindung dan memijah bagi biota laut sehingga kondisi terumbu karang memegang peranan penting dalam peningkatan produktivitas di bidang perikanan serta mampu melindungi pantai dari ancaman abrasi (Hadi et al., 2018). Bali merupakan salah satu destinasi pariwisata bahari di Indonesia. Aktivitas 
wisata bahari akan berdampak pada keberlangsungan hidup ekosistem terumbu karang. Salah satu daerah yang memiliki potensi ancaman terhadap keberlangsngan hidup terumbu karang adalah Tanjung Benoa dan Jemeluk Amed.

Tanjung benoa secara administrasi terletak di Kecamatan Kuta Selatan Kabupaten Badung. Daerah ini mengalami perekembangan sebagai daerah wisata yang semula sebagaian besar penduduk lokalnya merupakan nelayan. Jumlah wisatawan di Kabupaten Badung meningkat dari 249.845 di tahun 2003 menjadi 1.551.954 di tahun 2014 (BPS, 2015). Luas tutupan terumbu karang Kecamatan Kuta Selatan 1,021 ha dengan kondisi terumbu karang 17,86 \% sangat baik dan 9,60\% rusak (SLHD Kab. Badung, 2014). Jemeluk Amed terletak di Kecamatan Abang Kabupaten Karangasem memiliki keindahan bawah laut menarik wisatawan mancanegara dan domestik sebagai tempat untuk snorkling dan diving. Hal ini dapat dilihat dari jumlah wisatawan di Kabupaten Karangasem meningkat dari 157,150 di tahun 2003 menjadi 423,740 di tahun 2014 (BPS, 2015). Luas tutupan terumbu karang Kecamatan Abang Desa Purwakerti 11 ha dengan kondisi terumbu karang 28,3\% sangat baik dan 47,3\% rusak (SLHD Kab. Karangasem, 2013). Tujuan dari penelitian ini adalah mengalisis kondisi terumbu karang (life form), menganalisis factor yang mempengaruhi kerusakan ekosistem terumbu karang dan merumuskan strategi pengelolaan terumbu karang di daerah wisata air Tanjung Benoa dan Jemeluk Amed, Bali.

\section{METODOLOGI}

Lokasi penelitian terletak di Tanjung Benoa Kecamatan Kuta Selatan Kabupaten Badung dan Jemeluk Amed
Kecamatan Abang Kabupaten Karangasem, Provinsi Bali (Gambar 1). Dalam penelitian ini diambil delapan stasiun pengamatan dengan rincian empat stasiun di Tanjung Benoa dan empat stasiun di Jemeluk Amed dan tiap stasiun terdapat dua kedalaman yang akan diteliti. Penelitian dilaksanakan dalam bulan Mei 2016 sampai dengan bulan Desember 2017. Prosedur penelitian terdiri dari pengukuran variabel biofisik yaitu mengukur kondisi terumbu karang berdasarkan life form dan parameter lingkungan pembatas. Metode wawancara, kuisioner dan observasi dilakukan untuk menjawab variabel sosial. Metode untuk mengetahui kondisi terumbu karang berdasrkan life form adalah dengan metode Line Intercept Transek (LIT). Metode LIT dengan cara membentangkan roll meter yang sejajar garis pantai sepanjang $80 \mathrm{~m}$ disetiap stasiun pengamatan yang diletakkan pada perwakilan kedalaman dangkal yaitu 3 meter dan perwakilan kedalaman dalam yaitu $10 \mathrm{~m}$. Roll meter dibentangkan sepanjang $80 \mathrm{~m}$ terinci dengan pertama didata dari titik $0 \mathrm{~m}$ sampai titik $20 \mathrm{~m}$ kemudian diberi interval/jarak $10 \mathrm{~m}$, transek kedua dimulai dari titik $30 \mathrm{~m}$ kemudian diberi interval/jarak $10 \mathrm{~m}$, dan ketiga dari titik $60 \mathrm{~m}$ sampai dengan $80 \mathrm{~m}$ dengan mencatat jenis karang setiap $\mathrm{cm}$ yang berada di bawah rol meter (English et al., 1997). Metode yang digunakan untuk merumuskan perencanaan strategi pengelolaan ekosistem terumbu karang meliputi Strengths, Weaknesses, Opportunities dan Threats (SWOT). Metode ini dilakukan dengan membandingkan antara faktor external meliputi opportunities dan threats, dan faktor internal meliputi strengths dan weaknesses (Rangkuti, 2015). 


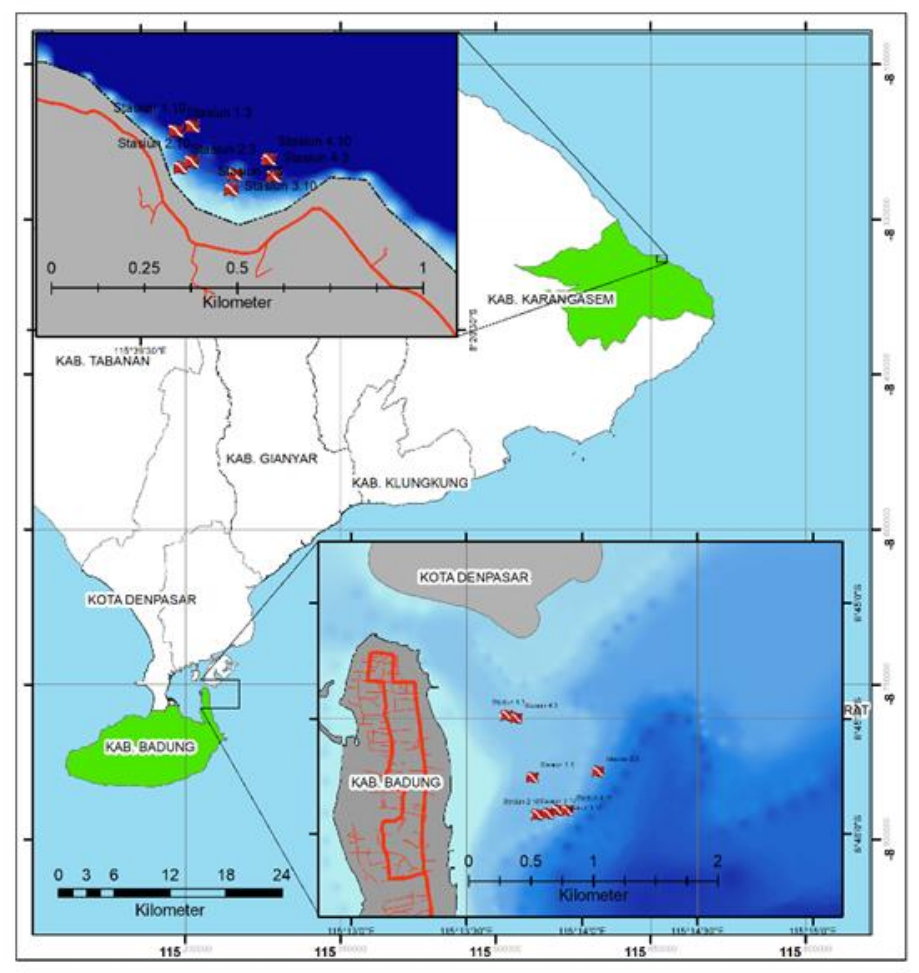

Gambar 1.

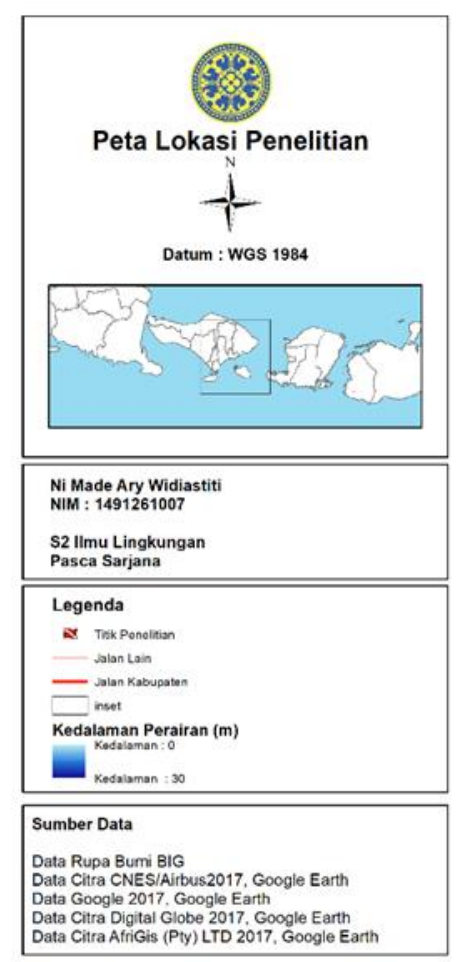

Data Citra Digital Globe 2017, Google Earth
Data Cirra AfriGis (Pty) LTD 2017, Google Earth

Peta Lokasi Tanjung Benoa dan Jemeluk Amed

\section{HASIL DAN PEMBAHASAN}

\subsection{Lokasi Penelitian Tanjung Benoa}

Kedalaman dasar perairan 3 meter

(Gambar 2) nilai persentase tutupan terumbu karang hidup antara 1,67\% $16,87 \%$ dengan nilai rata-rata $9,18 \%$ termasuk dalam kategori buruk (English et al., 1997). Persentase karang hidup tertinggi berdasarkan pengukuran life form terdapat pada Stasiun II. Persentase karang mati antara 16,67 \% - 38,07\% dengan persentase tertinggi pada Stasiun II. Persentase bentik lain antara 20\% $43,83 \%$ dengan persentase tertinggi pada Stasiun I. Persentase abiotik antara
$10,83 \%$ - 60,83\% dengan persentase tertinggi pada Stasiun IV. Pada kedalaman dasar perairan 10 meter (Gambar 3) nilai persentase tutupan terumbu karang hidup antara 33,92\% $41,33 \%$ dengan nilai rata-rata $37,19 \%$ termasuk dalam kategori kondisi sedang. Persentase kondisi karang hidup tertinggi pada Stasiun IV. Persentase karang mati antara $11,75 \% \quad-\quad 27,33 \%$ dengan persentase tertinggi pada Stasiun II. Persentase bentik lain antara 20,25\% $33,08 \%$ dengan persentase tertinggi pada Stasiun III. Persentase abiotik antara $8,83 \%$ - 32,58\% dengan persentase tertinggi pada Stasiun I. 


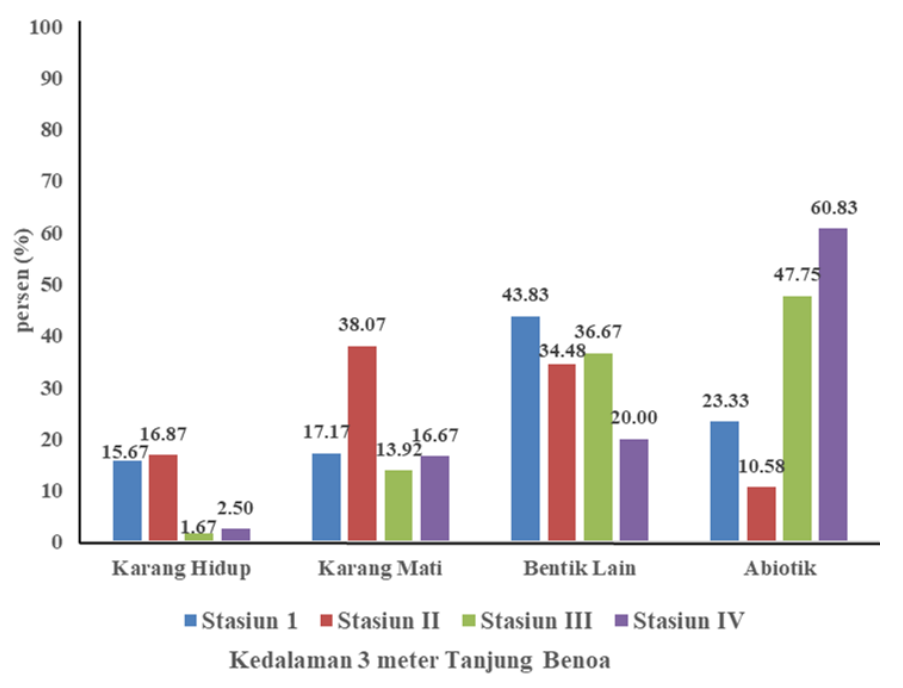

Gambar 2.

Persentase Tutupan Karang pada Kedalaman 3 m

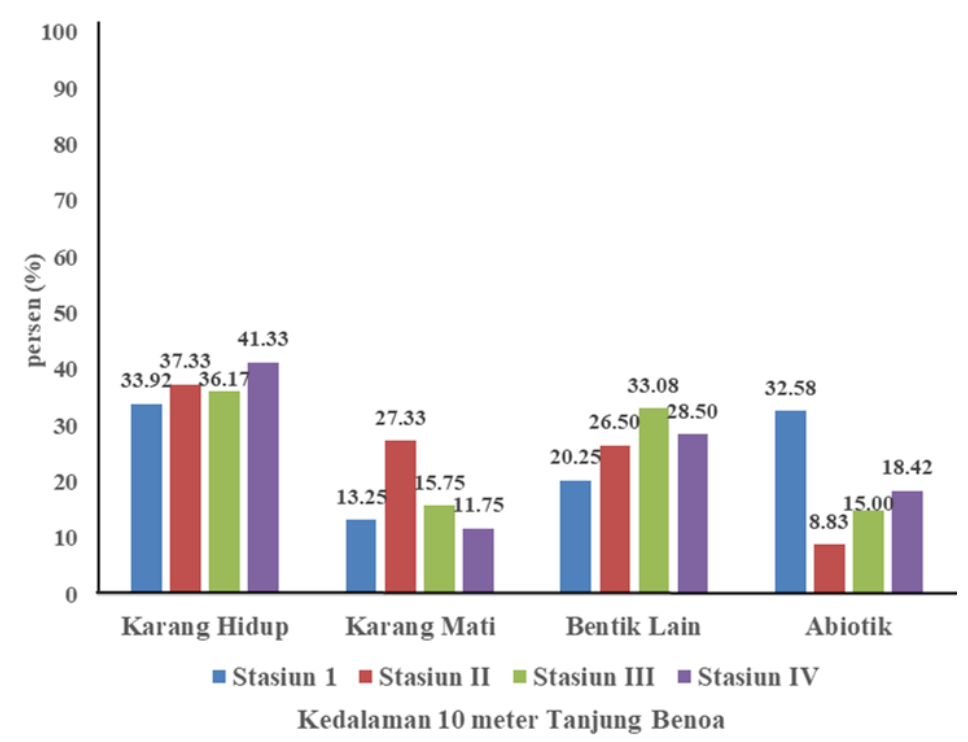

Gambar 3.

Persentase Tutupan Karang pada Kedalaman 10 m

Dari keempat stasiun tutupan karang hidup didominasi oleh Coral massive, hal ini bisa saja terjadi karena karang yang berbentuk massive dapat memakan jaringan koloni karang jenis lain yang menutupinya sehingga mencegah karang jenis bercabang yang pertumbuhannya menjadi terhambat (Nybakken, 1988). Walaupun memiliki kecepatan bereproduksi yang sama, jenis karang bercabang lebih rentan terhadap ganguan alam dan fisik seperti mudah rusak atau patah apabila mendapat benturan yang keras, sedangkan jenis karang massive lebih bisa bertahan (Sudiono, 2008).

Suhu perairan pada lokasi pengamatan berkisar antara $28-29{ }^{\circ} \mathrm{C}$, suhu tersebut tergolong bersifat baik untuk pertumbungan terumbu karang karena termasuk dalam kisaran suhu yang paling baik yaitu antara $25-32{ }^{\circ} \mathrm{C}$ (Supriharyono, 2000). Salinitas pada lokasi pengamatan berkisar antara 30 - 31 
$\%$, nilai tersebut menunjukkan kisaran yang baik untuk pertumbuhan terumbu karang yang sesuai dengan salinitas karang dapat hidup dengan subur antara 27 - 40\% (Nontji, 2005). Kecerahan merupakan kedalaman penetrasi cahaya matahari yang mempengaruhi penyebaran ekosistem terumbu karang. Kedalamn laut maksimum untuk karang dapat hidup dengan mendapatkan penetrasi cahaya matahari yang optimal dalam membentuk terumbu karang adalah $40 \mathrm{~m}$ (Nontji, 2005). Kecerahan air di lokasi pengamatan mendukung untuk pertumbuhan terumbu karang secara optimal dimana nilai kecerahan pada lokasi penelitian mencapai dasar perairan 3 meter dan 10 meter. Arus di daerah pengamatan berkisar antara $0,10-0,40$ $\mathrm{m} / \mathrm{s}$. Pertumbuhan karang akan lebih baik pada perairan yang berombak dan berarus daripada perairan yang tenang dan terlindungi (Nontji, 2007). Arus menyediakan makanan berupa mikroplankton dan memberikan oksigen untuk karang serta dapat membersihan endapan-endapan material yang terdapat pada karang (Dahuri, 2003). Berdasarkan analisis parameter fisika perairan (suhu, salinitas, kecerahan dan arus) diatas, bahwa kondisi parameter tersebut berada pada batas toleransi karang dapat berkembang dan hidup dengan baik.

Hasil pengamatan pada penelitian ini, diketahui bahwa faktor-faktor yang mempengaruhi kerusakan terumbu karang meliputi:

a. Pengembangan pariwisata dan dampak dari penangkapan ikan menggunakan bahaan peledak dan racun pada tahuntahun terdahulu yang ditandai dengan dijumpainya patahan-patahan terumbu karang. Salah satu faktor kerusakan terumbu karang akibat kegiatan manusia (antropogentik) adalah eksploitasi ikan dengan bahan peledak dan racun serta pengembangan daerah wisata (Ikawati et al., 2001) b. Dijumpai beberapa terumbu karang yang mengalami bleaching, ini bisa saja terjadi dikarenakan pada tahun 2015 - 2016 sebelum melakukan penelitian ini terjadinya perubahan iklim di sejumlah perairan yang ada di Bali. Hal ini sesuai dengan hasil analisis suhu permukaan laut (SPL) tahun 2015 - 2016 di perairan Bali yang diduga memperngaruhi kejadian pemutihan karang (Nuryana et al., 2018). Pemanasan global mengakibatkan suhu permukaan air laut meningkat yang mengakibatkan bleaching pada karang sehingga akan terancam rusak (Ikawati et al., 2001). Kematian karang dapat disebabkan oleh pemanasan suhu air laut atau peristiwa terkait iklim lainnya seperti bleaching (Steneck et al., 2019).

c. Aktifitas transpotasi kapal laut yang mendarat atau berlabuh dengan membuang jangkar secara tidak sengaja baik disembarang tempat maupun pada kawasan terumbu karang dapat menyebabkan karang rusak berupa patahan/pecahan dalam ukuran besar, demikian pula saat mengangkat jangkar (Wibisono, 2011). Pada lokasi penelitian di Tanjung Benoa dijumpai aktivitas pembuangan jangkar kapal yang disebabkan oleh tidak semua perairan memiliki mooring buoy. Moring buoy merupakan fasilitas untuk mengikat kapal sebagai pengganti jangkar yang terdiri dari beton pemberat, pelampung penambat, dan rantai atau tali antar beton pemberat (WWF, 2015) sehingga dapat mengancam terumbu karang yang ada di Tanjung Benoa.

d. Lokasi perairan Tanjung Benoa yang merupakan daerah wisata air yang lokasinya berdekatan dengan lokasi penduduk dan berhadapan langsung dengan penginapan dan hotel yang dibangun untuk para pengunjung, dimana aktivitas penyandaran kapal 
yang membawa pengunjung yang secara tidak disadari atau tidak diketahui kapal mengeluarkan minyak yang dipergunakan sebagai bahan bakar. Tumpahan minyak dari kapal kapal dapat mengganggu kesehatan karang bahkan dapat mematikan karang (Supriharyono, 2000).

e. Banyak ditemui algae pada kedalaman 3 meter. Hal ini merupakan penyebab kerusakan terumbu karang akibat faktor biologis yaitu bioerasi. Bioerosi merupakan proses pengrusakan karang baik secara mekanis dan kimiawi sebagai akibat terdegradasinya susunan kapur pada kerangka tubuh karang $\left(\mathrm{CaCO}_{3}\right)$ oleh aktivitas organisme lain salah satunya adalah alga yang melekat dicangkang (DKP, 2006)

Strategi Pengelolaan Ekosistem Terumbu Karang di Tanjung Benoa dapat dilakukan dengan stategi (SO) yaitu memanfaatkan kekuatan yang sebesarbesarnya untuk dapat meraih peluang yang ada, seperti; a)Kondisi terumbu karang yang baik apabila mendapat dukungan pemerintah dan LSM dalam pengembangan kegiatan ramah lingkungan dan kajian monitoring dalam mempertahankan kondisi terumbu karang tetap lestari, menurut Ikawati dkk (2001), salah satu upaya pengelolaan ekosistem terumbu karang adalah program pengelolaan terumbu karang oleh pemerintah, pelajar dan organisasi masyarakat. b)Menerapkan aturan kelestarian terumbu karang (larangan pengambilan terumbu karang pada pararem/kesepakatan desa adat) dengan dukungan masyarakat yang bersedia membantu serta adanya kolaborasi pemerintah dan LSM untuk melakukan rehabilitasi terumbu karang dan kajian monitoring, menurut Ikawati dkk (2001), salah satu upaya pengelolaan ekosistem terumbu karang adalah pengelolaan berbasis masyarakat yang diharapkan dapat aktif mulai dari tahap perencanaan sampai pelaksanaan serta pemantauan kegiataan tersebut serta melibatkan LSM lokal yang akan menjadi pendamping atau motivator. Salah satu kebijakan nasional dalam upaya pengelolaan terumbu karang adalah pengakuan hak-hak ulayat dan pranata sosial persekutuan masyarakat adat tentang pengelolaan terumbu karang yang tercantum dalam Keputusan Menteri Kelautan dan Perikanan Nomor 38/MEN/2004. c)Tanjung Benoa sebagai salah satu daerah pariwisata perlu adanya peran perguruan tinggi untuk penelitian berkelanjutan tentang kondisi terumbu karang menjadi pariwisata ramah lingkungan dan berkelanjutan, salah satu kebijakan nasional pengelolaan terumbu karang melalui peran perguruan tinggi adalah pengelolan berdasarkan data ilmiah yang tersedia dan kemampuan daya dukung lingkungan yang tercantum dalam Keputusan Menteri Kelautan dan Perikanan Nomor 38/MEN/2004.

\subsection{Lokasi Penelitian Jemeluk Amed}

Kedalaman dasar perairan 3 meter (Gambar 4) nilai persentase tutupan terumbu karang hidup antara $42,42 \%$ $50,50 \%$ dengan nilai rata-rata $46,11 \%$ termasuk dalam kategori sedang. Persentase karang hidup tertinggi berdasarkan pengukuran life form terdapat pada Stasiun III. Persentase karang mati antara $15 \%-23,75 \%$ dengan persentase tertinggi pada Stasiun I. Persentase bentik lain antara $1,83 \%$ - $7,67 \%$ dengan persentase tertinggi pada Stasiun IV. Persentase abiotik antara $27,50 \%$. $36,67 \%$ dengan persentase tertinggi pada Stasiun II. Pada kedalaman dasar perairan 10 meter (Gambar 5) nilai persentase tutupan terumbu karang hidup antara $19,42 \%$ - 39,08\% dengan nilai rata-rata $28,19 \%$ termasuk dalam kategori sedang. Persentase kondisi karang hidup tertinggi pada Stasiun IV. Persentase karang mati antara $13,50 \% \quad-22,42 \%$ dengan persentase tertinggi pada Stasiun 3. 
Persentase bentik lain antara 12,50\% $19 \%$ dengan persentase tertinggi pada Stasiun IV. Persentase abiotik antara $28.42 \%-50 \%$ dengan persentase tertinggi pada Stasiun I. Dari keempat stasiun tutupan karang hidup didominasi oleh Coral massive, hal ini bisa saja terjadi seperti kondisi di Tanjung Benoa dan Jemeluk Amed pada kedalamn 3 meter.

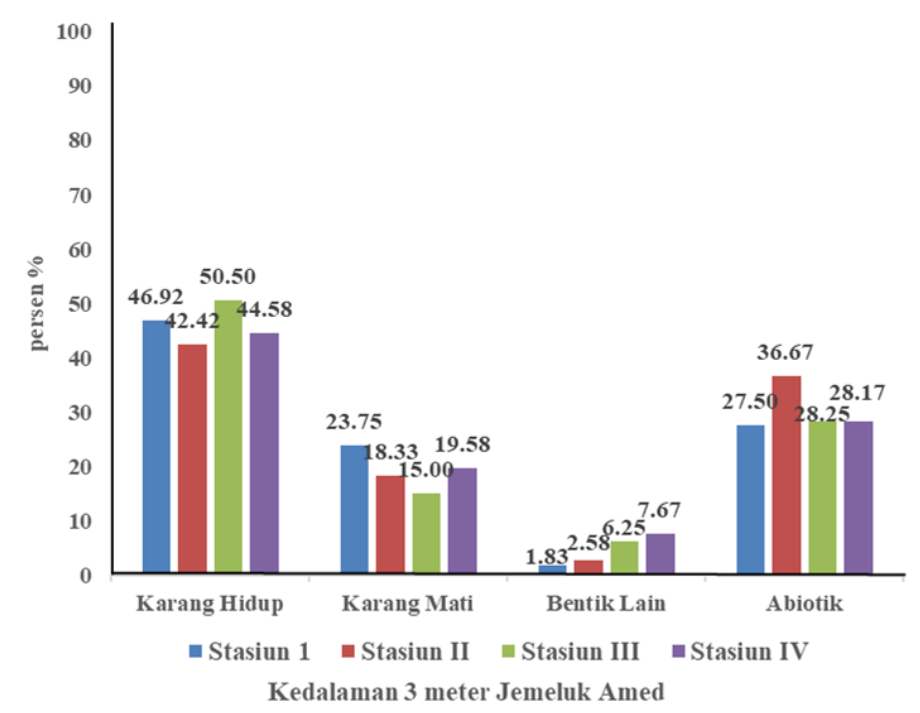

Gambar 4.

Persentase Tutupan Karang pada Kedalaman 3 m

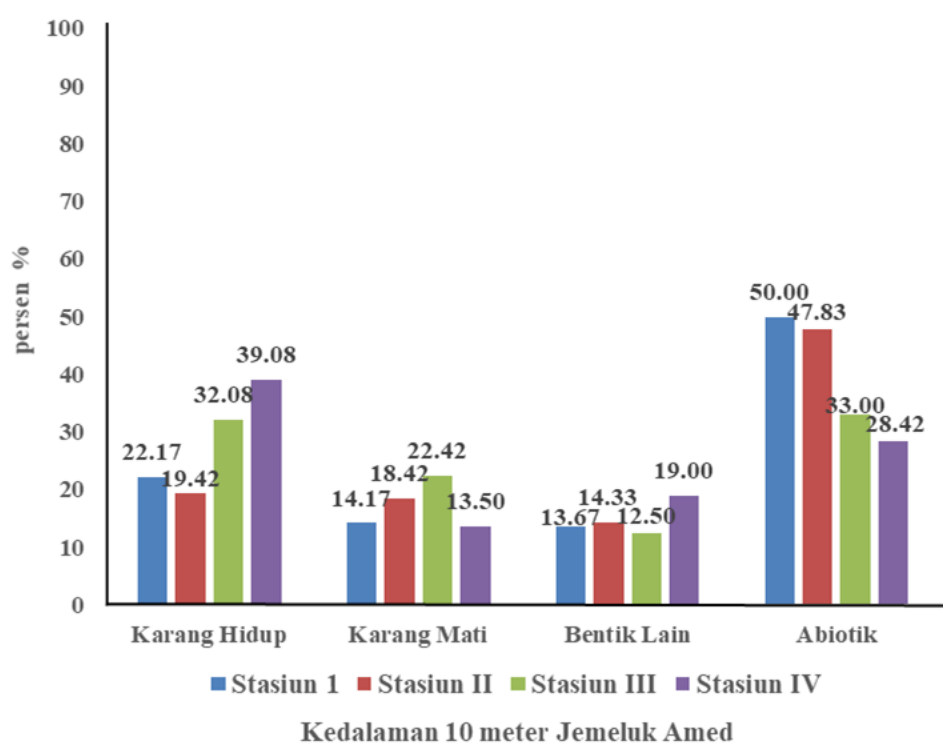

Gambar 5.

Persentase Tutupan Karang pada Kedalaman 10 Meter

Suhu perairan pada lokasi (Supriharyono, 2000). Salinitas pada pengamatan berkisar antara $29-30{ }^{\circ} \mathrm{C}$, lokasi pengamatan berkisar antara $32-33$ suhu tersebut tergolong bersifat baik \%o, nilai tersebut menunjukkan kisaran untuk pertumbuhan terumbu karang yang baik untuk pertumbuhan terumbu karena termasuk dalam kisaran suhu yang karang yang sesuai dengan salinitas paling baik yaitu antara $25-32{ }^{\circ} \mathrm{C}$ karang dapat hidup dengan subur antara 
27 - 40\%o (Nontji, 2005). Kecerahan merupakan kedalaman penetrasi cahaya matahari yang mempengaruhi penyebaran ekosistem terumbu karang. Kedalaman laut maksimum untuk karang dapat hidup dengan mendapatkan penetrasi cahaya matahari yang optimal dalam membentuk terumbu karang adalah $40 \mathrm{~m}$ (Nontji, 2005). Kecerahan air di lokasi pengamatan mendukung untuk pertumbuhan terumbu karang secara optimal dimana nilai kecerahan pada lokasi penelitian mencapai dasar perairan 3 meter dan 10 meter. Arus di daerah pengamatan berkisar antara $0,05-0,10$ $\mathrm{m} / \mathrm{s}$. Pertumbuhan karang akan lebih baik pada perairan yang berombak dan berarus daripada perairan yang tenang dan terlindungi (Nontji, 2007). Arus menyediakan makanan berupa mikroplankton dan memberikan oksigen untuk karang serta dapat membersihan endapan-endapan material yang terdapat pada karang (Dahuri, 2003). Berdasarkan analisi parameter fisika perairan (suhu, salinitas, kecerahan dan arus) diatas, bahwa kondisi parameter tersebut berada pada batas toleransi karang dapat berkembang dan hidup dengan baik.

Hasil pengamatan pada penelitian ini, diketahui bahwa faktor-faktor mempengaruhi kerusakan terumbu karang meliputi:

a. Pengembangan pariwisata dan dampak dari penangkapan ikan menggunakan bahaan peledak dan racun pada tahuntahun terdahulu yang ditandai dengan dijumpainya patahan-patahn terumbu karang. Salah satu faktor kerusakan terumbu karang akibat kegiatan manusia (antropogentik) adalah eksploitasi ikan dengan bahan peledak dan racun serta pengembangan daerah wisata (Ikawati et al., 2001)

b. Dijumpai beberapa terumbu karang yang mengalami bleaching, ini bisa saja terjadi dikarenakan pada tahun 2015 - 2016 sebelum melakukan penelitian ini terjadinya perubahan iklim di sejumlah perairan yang ada di Bali. Hal ini sesuai dengan hasil analisis suhu permukaan laut (SPL) tahun 2015 - 2016 di perairan Bali yang diduga memperngaruhi kejadian pemutihan karang (Nuryana et al., 2018). Pemanasan global mengakibatkan suhu permukaan air laut meningkat yang mengakibatkan bleaching pada karang sehingga akan terancam rusak (Ikawati et al., 2001). Kematian karang dapat disebabkan oleh pemanasan suhu air laut atau peristiwa terkait iklim lainnya seperti bleaching (Steneck et al., 2019).

c. Aktifitas transpotasi kapal laut yang mendarat atau berlabuh dengan membuang jangkar secara tidak sengaja baik disembarang tempat maupun pada kawasan terumbu karang dapat menyebabkan karang rusak berupa patahan/pecahan dalam ukuran besar, demikian pula saat mengangkat jangkar (Wibisono, 2011). Pada lokasi penelitian di Jemeluk Amed dijumpai aktivitas pembuangan jangkar kapal yang disebabkan oleh tidak semua perairan memiliki mooring buoy. Moring buoy merupakan fasilitas untuk mengikat kapal sebagai pengganti jangkar yang terdiri dari beton pemberat, pelampung penambat, dan rantai atau tali antar beton pemberat (WWF, 2015) sehingga dapat mengancam terumbu karang yang ada di Jemeluk Amed.

d. Lokasi perairan Jemeluk Amed merupakan daerah wisata air yang lokasinya berdekatan dengan lokasi penduduk dan berhadapan langsung dengan penginapan dan hotel yang dibangun untuk para pengunjung. Aktivitas penyandaran kapal yang membawa pengunjung yang secara tidak disadari atau tidak diketahui kapal mengeluarkan minyak yang dipergunakan sebagai bahan bakar. 
Tumpahan minyak dari kapal - kapal dapat mengganggu kesehatan karang bahkan dapat mematikan karang (Supriharyono, 2000).

Strategi Pengelolaan Ekosistem Terumbu Karang di Jemeluk Amed dapat dilakukan dengan strategi (SO) yaitu memanfaatkan kekuatan yang sebesarbesarnya untuk meraih peluang yang ada, seperti; a)Kondisi terumbu karang yang baik apabila mendapat dukungan pemerintah dan LSM dalam pengembangan kegiatan ramah lingkungan dan kajian monitoring dalam mempertahankan kondisi terumbu karang tetap lestari, menurut Ikawati dkk (2001), salah satu upaya pengelolaan ekosistem terumbu karang adalah Program pengelolaan terumbu karang oleh pemerintah, pelajar dan organisasi masyarakat. b)Menerapkan aturan kelestarian terumbu karang (larangan pengambilan terumbu karang pada pararem/kesepakatan desa adat) dengan dukungan masyarakat yang bersedia membantu serta adanya kolaborasi pemerintah dan LSM untuk melakukan rehabilitasi terumbu karang dan kajian monitoring, menurut Ikawati dkk (2001), salah satu upaya pengelolaan ekosistem terumbu karang adalah pengelolaan berbasis masyarakat yang diharapkan dapat aktif mulai dari tahap perencanaan sampai pelaksanaan serta pemantauan kegiataan tersebut serta melibatkan LSM lokal yang akan menjadi pendamping atau motivator. Salah satu kebijakan nasional dalam upaya pengelolaan terumbu karang adalah pengakuan hak-hak ulayat dan pranata sosial persekutuan masyarakat adat tentang pengelolaan terumbu karang yang tercantum dalam Kepmen Kelautan dan Perikanan Nomor 38/MEN/2004. c)Jemeluk Amed sebagai salah satu daerah pariwisata perlu adanya peran perguruan tinggi untuk penelitian berkelanjutan tentang kondisi terumbu karang menjadi pariwisata ramah lingkungan dan berkelanjutan, salah satu kebijakan nasional pengelolaan terumbu karang melalui peran perguruan tinggi adalah pengelolan berdasarkan data ilmiah yang tersedia dan kemampuan daya dukung lingkungan yang tercantum dalam Kepmen Kelautan dan Perikanan Nomor 38/MEN/2004.

\section{SIMPULAN DAN SARAN}

\subsection{Simpulan}

Kondisi tutupan terumbu karang hidup di Tanjung Benoa pada kedalaman dasar perairan 3 meter termasuk dalam kategori buruk, sedangkan pada kedalaman dasar perairan 10 meter termasuk dalam kondisi sedang. Kondisi tutupan terumbu karang hidup di Jemeluk Amed kedalaman dasar perairan 3 meter termasuk dalam kategori sedang, dan pada kedalaman dasar perairan 10 meter juga termasuk dalam kategori sedang. Kondisi terumbu karang di Tanjung Benoa dan Jemeluk Amed pada kedalaman 10 meter memiliki kondisi yang sama yaitu sedang, akan tetapi untuk kedalaman 3 meter terdapat perbedaan dimana terumbu karang di Jemeluk Amed lebih bagus dengan kondisi sedang dibandingkan di Tanjung Benoa yang dalam kondisi buruk.

Faktor-faktor penyebab kerusakan ekosistem terumbu karang di daerah wisata air Tanjung Benoa dan Jemeluk Amed adalah ; terumbu karang yang telah dipengaruhi oleh aktivitas manusia (antropogenetik), beberapa terumbu karang mengalami bleaching, aktivitas pembuangan jangkar dan tumpahan minyak dari kapal - kapal. Di Tanjung Benoa banyak ditemui algae pada kedalaman 3 meter.

Strategi pengelolaan ekosistem terumbu karang di Tanjung Benoa dan Jemeluk Amed yang dilakukan adalah secara progresif (Kuadran I; Positif; Positif), yaitu memanfaatkan kekuatan yang sebesar-besarnya untuk meraih 
peluang yang ada (SO), adalah: a) Kondisi terumbu karang yang baik apabila mendapat dukungan pemerintah dan LSM dalam pengembangan kegiatan ramah lingkungan dan kajian monitoring dalam mempertahankan kondisi terumbu karang tetap lestari, b) Menerapkan aturan kelestarian terumbu karang (larangan pengambilan terumbu karang pada pararem/kesepakatan desa adat) dengan dukungan masyarakat yang bersedia membantu serta adanya kolaborasi pemerinta dan LSM untuk melakukan rehabilitasi terumbu karang dan kajian monitoring, dan c) Tanjung Benoa dan Jemeluk Amed sebagai salah satu daerah pariwisata perlu adanya peran perguruan tinggi untuk penelitian berkelanjutan tentang kondisi terumbu karang menjadi pariwisata ramah lingkungan dan berkelanjutan.

\subsection{Saran}

Untuk mendukung kegiatan pengelolaan ekosistem terumbu karang di Tanjung Benoa dan Jemeluk Amed diperlukan kerjasama antar lembaga terkait baik pemerintah, swasta, masyarakat setempat dan wisatawan yang berkunjung. Saran yang dapat diberikan meliputi:

1. Penelitian berkelanjutan untuk mengetahui perkembangan kondisi terumbu karang

2. Komitmen untuk seluruh pihak baik pemerintah, swasta, masyarakat dan wisatawan untuk menjaga kelestarian terumbu karang.

\section{DAFTAR PUSTAKA}

Badan Pusat Statistik. 2015. Perkembangan Jumlah Kunjungan Wisatawan pada Daya Tarik Wisata Di Bali. http://bali.bps.go.id diakses pada tanggal 20 November 2015.
Dahuri, R., Jacob Rais, Sapta Putra Ginting dan M.J. Sitepu, 2001. Pengelolaan Sumber Daya Wilayah Pesisir dan Lautan Secara Terpadu. Pradnya Paramita. Jakarta.

Dahuri, R. 2003. Keanekaragaman Hayati Laut, Aset Pembangunan Berkelanjutan Indonesia. PT. Gramedia Pustaka Utama. Jakarta.

Departemen Kelautan dan Perikanan. 2006. Petunjuk Pelaksanaan Transplantasi Karang. Jakarta.

English, S., Wilkinson, C, and Baker, V. 1997. Survey Manual For Tropical Marine Resources. Australian Institute Of Marine Science. Australia.

Hadi T.A., Giyanto, Prayudha B., Hafizt M., Budiyanto A., dan Suharsono. 2018. Status Terumbu Karang Indonesia 2018. Pusat Penelitian Oseanologi. LIPI.

Ikawati, Y., Hanggarawati, P.S., Parlan, H., Handini, H dan Siswodihardjo, B. 2001. Terumbu karang di Indonesia. Masyarakat Penulis Ilmu Pengetahuan dan Teknologi (MAPPIPTEK). Jakarta.

Indonesia, Keputusan Menteri Kelautan dan Kelautanm tentang pedoman umum pengelolaan terumbu karang, Kepmen nomor 38 Tahun 2004.

Nontji, A. 2005. Laut Nusantara. Djambatan. Jakarta.

2007. Laut Nusantara. Djambatan. Jakarta.

Nuryana, J., Hendrawan, I.G., dan Karim, W. 2018. Pendugaan Kejadian Pemutihan Karang Berdasarkan Analisis Suhu Permukaan laut (SPL) Tahun 2015 - 2016 di Perairan Bali. Journal of Marine and Aquatic Sciences. (4)2, 286 296. 
Nybakken, J.W. 1988. Biologi Laut: Suatu Pendekatan Ekologis. PT. Gramedia. Jakarta.

Rangkuti, F., 2015, Analisis SWOT Teknik Membedah Kasus Bisnis, PT. Gramedia Pustaka Utama, Jakarta.

Status Lingkungan Hidup Daerah (SLHD) Kabupaten Badung. 2014. Laporan Status Lingkungan Hidup Daerah Kabupaten Badung Tahun 2014. Pemerintahan Kabupaten Badung. Bali.

Status Lingkungan Hidup Daerah (SLHD) Kabupaten Karangasem. 2013. Laporan Status Lingkungan Hidup Daerah Kabupaten Karangasem Tahun 2013. Pemerintahan Kabupaten Karangasem. Bali.
Steneck R.S., Arnold S.N., Boenish R., Leon R.D., Mumby P.J., Rasher D.B., and Wilson M.W. 2019. Managing Recovery Resilience in Coral Reefs Against ClimateInduced Bleaching and Hurricanes: A 5 Year Case Study From Bonaire, Dutch Caribbean. Frontiers in Marine Science. 6:265.

Supriharyono. 2000. Pengelolaan Ekosistem Terumbu Karang. Djambatan, Jakarta.

Wibisono, M.S. 2011. Pengantar Ilmu Kelautan. Universita Indonesia. Jakarta.

World Wildlife Fund Indonesia, 2015. Best Environmental Equitable Practices : Pemasangan Alat Tambat Apung (Mooring buoy). Jakarta. 